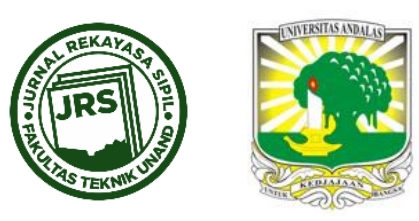

\title{
APLIKASI METODE EKSPERIMEN RESPONSE SURFACE UNTUK MENGOPTIMALKAN KUAT TEKAN BATA NON BAKAR
}

\author{
JAUHAR FAJRIN ${ }^{1}$, HARIYADI ${ }^{2}$, NADELLA MARCHELINA ${ }^{3}$ \\ ${ }^{1} J u r u s a n$ Teknik Sipil, Fakultas Teknik, Universitas Mataram(\jauhar.fajrin@unram.ac.id) \\ 2Jurusan Teknik Sipil, Fakultas Teknik,Universitas Mataram (hariyadi@unram.ac.id) \\ ${ }^{3}$ Alumni Jurusan Teknik Sipil, Fakultas Teknik, Universitas Mataram (nadellamarchelina@gmail.com)
}

Naskah diterima : 21 Agustus 2017. Disetujui: 22 September 2017. Diterbitkan : 22 Oktober 2017

\begin{abstract}
ABSTRAK
Sebagai bahan bangunan yang relatif masih baru, komposisi bahan penyusun bata non-bakar masih menjadi topik yang menarik untuk diteliti. Pada beberapa studi sebelumnya upaya mencari komposisi optimum campuran bata non bakar menggunakan metode eksperimen yang mengevaluasi pengaruh sebuah faktor dalam satu kali eksperimen atau yang dikenal dengan istilah single factor experiment. Kelemahan dari metode eksperimen ini adalah kesimpulan yang dihasilkan hanya terkait dengan satu faktor yang diamati itu saja. Sementara dalam kenyataannya, hasil dari sebuah proses tidak hanya dipengaruhi oleh satu faktor saja melainkan dipengaruhi oleh banyak faktor termasuk interaksinya. Studi ini dilakukan untuk mencari komposisi optimum bahan penyusun bata non bakar dengan menerapkan metode respon permukaan (Response Surface Method). Proses analisa data dilakukan dengan menggunakan software Minitab 17 . Hasil penelitian menunjukan bahwa proporsi bahan yang menghasilkan kuat tekan paling optimal adalah semen (21,034\%), pasir (28,9651\%) dan tanah liat (50\%), yang mampu menghasilkan bata non bakar dengan kuat tekan rata-rata sebesar $50.22 \mathrm{~kg} / \mathrm{cm} 2$. Hasil penelitian ini juga merekomendasikan sebuah persamaan umum untuk memprediksi kuat tekan bata non bakar apabila menggunakan ketiga komposisi bahan tersebut, yaitu: $y=-5,56 x_{1}+$ $0,141 x_{2}+0,541 x_{3}+0,214 x_{1} x_{2}+0,0473 x_{1} x_{3}-0,307 x_{2}$ dengan $x 1, x 2$ dan $x 3$ masing-masing adalah proporsi semen, pasir dan tanah liat.
\end{abstract}

Kata kunci : bata non bakar, metode response surface, desain eksperimen, Minitab

\section{PENDAHULUAN}

Batu bata atau bata merah sudah menjadi bagian dari kultur membangun masyarakat Indonesia. Meskipun ada beberapa bahan bangunan lain yang diperkenalkan untuk membuat rumah seperti batako, dominasi penggunaan bata merah tetap terlihat. Salah satu alasan yang membuat bata merah lebih disukai adalah karena kemudahannya dibongkar pasang ketika rumah direnovasi. Namun demikian, bata merah yang ada di Indonesia mempunyai satu kelemahan yang mendasar karena dalam proses pembuatannya memakan waktu lama dan harus melalui proses pembakaran yang seringkali menyebabkan kualitas bata menjadi kurang seragam. Solusi untuk mengatasi masalah ini adalah dengan 
menggunakan bata non bakar. Saat ini sudah cukup banyak ditemui produk bata non bakar seperti yang diklaim sebagai bata ringan dengan berbagai merek komersial yang dijual dipasaran. Sebagai bahan bangunan yang relatif masih baru, komposisi bahan penyusun bata non-bakar masih menjadi topik yang menarik untuk diteliti. Beberapa peneliti sebelumnya telah melakukan studi untuk mengetahui komposisi optimum dari bahan penyusun bata non bakar. Secara umum bata non bakar terdiri dari tanah liat, pasir dan semen. Primayatma (1993) dalam Sudarsana dkk (2011) merekomendasikan komposisi tanah liat, aggregat dan semen masing-masing sebesar $60 \%$, 20\%, dan $20 \%$. Komposisi ini bisa menghasilkan bata dengan kuat tekan sekitar $28 \mathrm{~kg} / \mathrm{cm}^{2}$. Agregat yang digunakan adalah campuran pasir, abu gosok dan serbuk batu paras dalam proporsi yang sama. Penelitian yang lebih baru dilaporkan oleh Amin (2014) menghasilkan bata non bakar dengan kuat tekan yang lebih tinggi, yakni $52,60 \mathrm{~kg} / \mathrm{cm} 2$ dengan cara mencampurkan 0,13 persen serbuk besi kedalam campuran utama bata non bakar. Komposis tepatnya adalah tanah liat (59,92\%), semen (9.99\%), pasir (29.96\%) dan serbuk bijih besi (0.13\%).

Pada kedua penelitian yang telah disebutkan diatas, metode penelitian yang digunakan adalah metode yang mengevaluasi pengaruh sebuah faktor dalam satu kali eksperimen. Faktor tersebut kemudian dilevelkan menjadi beberapa variasi. Dalam istilah penelitian pendekatan ini dinamakan "single factor experiment" atau yang diartikan sebagai eksperimen faktor tunggal. Aplikasi metode penelitian faktor tunggal ini dalam studi tentang material telah banyak dilakukan, antara lain seperti yang dilaporkan oleh Fajrin dkk (2011a, 2011-b, 2013, 2015), Fajrin (2016), Fajrin dkk (2016). Namun demikian, metode ini mempunyai kelemahan yang cukup mendasar yaitu kesimpulan yang dihasilkan hanya terkait dengan satu faktor yang diamati itu saja. Sementara dalam kenyataanya, hasil dari sebuah proses tidak hanya dipengaruhi oleh satu faktor saja melainkan dipengaruhi oleh banyak faktor yang lain. Misalnya untuk bata non bakar, hasil yang berupa kualitas fisik dan mekanik tergantung dari perilaku bahan penyusunnya serta interaksi antara material tersebut selama proses pembuatan dan setelah menjadi produk. Salah satu metode eksperimen yang bisa digunakan untuk memperhitungkan kontribusi lebih dari satu faktor dalam satu kali eksperimen adalah Response Surface Method atau yang dalam bahasa Indonesia diterjemahkan sebagai metode permukaan respons (Dewi dkk, 2013). Selain bisa memperhitungkan kontribusi dua atau lebih faktor dalam sebuah eksperimen, metode ini juga bisa memperkirakan interaksi antara faktor-faktor yang diamati sehingga memudahkan dalam mengambil kesimpulan variabel apa yang berpengaruh besar pada respon. Artikel ini akan membahas hasil studi eksperimen untuk mencari komposisi optimum dari bahan penyusun bata non bakar dengan menerapkan metode respon surface. Proses analisa data dilakukan dengan menggunakan software Minitab 17.

\section{METODE DESAIN EKSPERIMEN RESPONSE SURFACE}

Desain eksperimen (Design of Experiment/DOE) merupakan metode yang digunakan untuk meningkatkan dan memperbaiki performa suatu proses, biasanya dalam sistem kualitas. Desain eksperimen dapat didefinisikan sebagai suatu uji atau rentetan uji dengan mengubah-ubah variabel input (faktor) suatu proses sehingga dapat diketahui penyebab perubahan output (respon). Salah satu disain eksperimen yang biasa digunakan adalah disain eksperimen dengan metode permukaan respon atau biasa disebut response surface methodology (RSM). Ide dasar metode ini adalah memanfaatkan desain eksperimen dengan bantuan statistika untuk mencari nilai optimal dari suatu respon (Montgomery, 2009). Peneliti dapat mengetahui nilai variabel-variabel independen yang menyebabkan nilai variabel respon menjadi optimal dengan menyusun suatu model matematika. Hubungan antara respon $\mathrm{y}$ dan variabel bebas $\mathrm{x}$ adalah sebagai berikut: 


$$
y=f\left(x_{1}, x_{2}, \ldots, x_{k}\right)+\varepsilon
$$

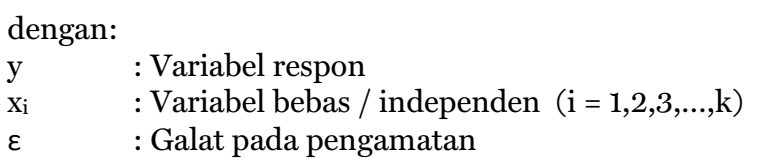

Hal pertama yang dilakukan pada eksperimen yang menggunakan metode response surface adalah mencari bentuk hubungan antara respon (y) dengan perlakuannya atau variable bebasnya $(\mathrm{x})$. Bentuk hubungan yang pertama kali dicoba adalah bentuk linier. Bentuk linear ini memiliki pendekatan fungsi yang biasa disebut first order model. Bentuk kedua yang dicobakan jika pendekatannya bukan bentuk linear adalah bentuk kuadrat yang biasa disebut second model order (Montgomery, 2009). Pada masing-masing orde, dilakukan dua proses pengujian; pertama adalah uji simultan untuk mengetahui apakah variabel bebas secara bersama-sama berpengaruh signifikan terhadap respon dan kedua uji lack of fit untuk mengetahui kecocokan model. Cara pengambilan keputusan pada uji simultan adalah dengan mengecek nilai $\mathrm{F}$ atau nilai $\mathrm{P}$ (P value). Apabilai nilai FHitung $>\mathrm{FTabel}$, atau $\mathrm{P}$ value $<$ (tingkat signifikansi) maka kesimpulannya adalah variabel secara bersama-sama berpengaruh signifikan terhadap respon, yang bermakna bahwa modelnya cocok. Sebelum memutuskan apakah model benar-benar cocok atau tidak, maka harus dilakukan pengujian tahap kedua berupa uji lack of fit. Sebelumnya, hipotesis untuk uji ini harus ditentukan terlebih dahulu, yakni:

$$
\begin{aligned}
& \mathrm{H}_{\mathrm{o}}=\text { Tidak ada lack of-fit dalam model } \\
& \mathrm{H}_{1}=\text { Ada lack of-fit dalam model }
\end{aligned}
$$

Hipotesis nol $\left(\mathrm{H}_{0}\right)$ diterima apabila FHitung $<$ FTabel, yang menyatakan tidak ada lack of fit atau dengan kata lain modelnya cocok. Untuk menerima atau menolak $\mathrm{H}_{0}$ bisa juga dilakukan dengan mengecek $\mathrm{P}$ value nya; apabila nilainya lebih besar dari tingkat signifikansi yang dipilih $(\alpha)$ maka hipotesis nol diterima dan model dinyatakan cocok. Proses perhitungannya adalah sebagai berikut:

$$
\begin{aligned}
& \mathrm{SS}_{\text {murni }}=\sum_{\mathrm{i}=1}^{\mathrm{m}} \sum_{\mathrm{j}=1}^{\mathrm{ni}}\left(\mathrm{y}_{\mathrm{ij}}-\overline{\mathrm{y}}_{. . .}\right)^{2} \\
& \mathrm{SS}_{\mathrm{LOF}}=\mathrm{SS}_{\mathrm{E}}+\mathrm{SS}_{\mathrm{murni}} \\
& \mathrm{F}_{\text {hitung }}=\frac{\mathrm{MS}_{\mathrm{LOF}}}{\mathrm{MS}_{\text {Murni }}}
\end{aligned}
$$

Setelah ditentukan model mana yang cocok, model Orde I (firt order model) atau Orde II (second order model), selanjutnya dilakukan pengujian model eksperimen yang terdiri dari: uji koefisien regresi secara serentak dan individu, uji identik, dan uji distribusi normal. Pengujian asumsi identik bertujuan untuk memeriksa apakah varians residual dari model yang diperoleh sama penyebarannya. Residual adalah perbedaan antara variabel independen y dengan y prediksi berdasarkan nilai persamaan regresi. Asumsi identik terpenuhi jika plot antara residual versus fitted value tidak membentuk pola tertentu seperti mengumpul ditengah maupun berjajar yang berarti semua parameter faktor tidak berpengaruh signifikan (Ernawati, 2012). Sementara pemeriksaan asumsi kenormalan dilakukan dengan membuat plot antara residual dengan nilai probabilitas normal. Asumsi ini dapat diperiksa 
dengan menggunakan uji Kolmogorov-Smirnov dengan hipotesis $\triangle$ Maks yang dihasilkan $<$ $\triangle$ Maks Tabel.

\section{METODE PENELITIAN}

Formula bata non bakar memiliki tiga variabel bebas yaitu proporsi semen, pasir dan tanah liat. Proporsi nilai ini merupakan hasil pengukuran yang akan digunakan untuk melihat persamaan empiris untuk model orde pertama yang merepresentasikan hubungan antara variabel respon dengan variabel bebas. Kombinasi formula ini tersebut merupakan hasil perhitungan metode campuran (mixture-optimum). Metode eksperimen ini digunakan saat suatu sistem terdiri atas campuran beberapa komponen yang jumlah totalnya konstan, yakni $100 \%$. Respon yang diperoleh merupakan fungsi dari proporsi relatif tiap komponen dalam sistem (Maryati, 2015). Pada metode ini, faktor-faktor adalah komponen dari suatu campuran dan konsekuensinya taraf-taraf bersifat tidak saling bebas. Jika x1, x2, .., xk menotasikan proporsi dari $\mathrm{k}$ buah komponen dari suatu campuran, maka $\mathrm{x} 1+\mathrm{x} 2+\ldots+\mathrm{xk}=1$ $(100 \%)$.

Rancangan model eksperimen pada penelitian ini ditampilkan pada Tabel 1. Jumlah benda uji yang digunakan untuk tahap optimasi adalah 10 sampel dengan replikasi 3 kali, sehingga jumlah total sampel yang diuji $(\mathrm{N})$ adalah 30 buah. Nilai pengkodean untuk tabel diatas berdasarkan simplex lattice design dimana x1 adalah proporsi semen, $\mathrm{x} 2$ adalah proporsi pasir, x3 adalah proporsi tanah liat dan y adalah variable respon yaitu kuat tekan. Tanah liat dan pasir yang digunakan pada penelitian ini adalah tanah yang digunakan pada sentra produsen bata di daerah Kuripan, Lombok Barat. Sementara semen diperoleh dari toko bangunan di daerah Kekalek, Mataram dengan merek Tiga Roda yang merupakan jenis semen Portland.

Tabel 1. Komposisi campuran mortar yang digunakan dalam penelitian

\begin{tabular}{ccccc}
\hline \multirow{2}{*}{$\begin{array}{c}\text { Komposisi } \\
\text { Campuran }\end{array}$} & \multicolumn{2}{c}{ Prosentase berdasarkan berat untuk masing-masing bahan } \\
\cline { 2 - 4 } & Semen $\left(\mathrm{x}_{1}\right)$ & Pariabel) & \multirow{2}{*}{ Respon $(\mathrm{y})$} \\
\hline 1 & 30 & 20 & 50 & \\
2 & 8 & 42 & 50 & $\mathrm{y}_{1}$ \\
3 & 8 & 20 & 72 & $\mathrm{y}_{2}$ \\
4 & 19 & 31 & 50 & $\mathrm{y}_{3}$ \\
5 & 19 & 20 & 61 & $\mathrm{y}_{4}$ \\
6 & 8 & 31 & 61 & $\mathrm{y}_{5}$ \\
7 & 15 & 27 & 57 & $\mathrm{y}_{6}$ \\
8 & 23 & 24 & 53 & $\mathrm{y}_{7}$ \\
9 & 12 & 35 & 53 & $\mathrm{y}_{8}$ \\
10 & 12 & 23 & 65 & $\mathrm{y}_{9}$ \\
\hline
\end{tabular}

\section{HASIL DAN PEMBAHASAN}

\subsection{Pemeriksaan Kuat Tekan Bata Non Bakar}

Hasil pengujian kuat tekan bata non bakar ditampilkan pada Tabel 2. Ada 10 buah komposisi campuran yang diuji dan masing-masing komposisi terdiri dari 3 sampel. Sesuai dengan standar pengujian ASTM C67-02 (ASTM, 2002), bata diuji dalam bentuk yang telah menjadi pasangan bata dengan menggunakan adukan semen: pasir sebesar 1:3. Pengujian 
kuat tekan bata menggunakan alat Compressing Testing Machine (CTM) setelah bata mencapai umur 7 hari.

Tabel 2. Hasil pengujian kuat tekan bata non bakar

\begin{tabular}{ccccc}
\hline \multirow{2}{*}{$\begin{array}{c}\text { Komposisi } \\
\text { Campuran }\end{array}$} & \multicolumn{3}{c}{ Kuat Tekan Bata $\left(\mathrm{kg} / \mathrm{cm}^{2}\right)$} & $\begin{array}{c}\text { Kuat Tekan } \\
\text { Rata-Rata } \\
\left(\mathrm{kg} / \mathrm{cm}^{2}\right)\end{array}$ \\
\cline { 2 - 4 } & Sampel 1 & Sampel 2 & Sampel 3 & 31.88 \\
2 & 33.96 & 31.94 & 29.74 & 50.12 \\
3 & 51.52 & 48.76 & 50.34 & 29.9 \\
4 & 29.61 & 31.35 & 28.74 & 14.83 \\
5 & 15.53 & 13.13 & 15.82 & 11.84 \\
6 & 12.19 & 12.82 & 10.5 & 14.56 \\
7 & 14.81 & 13.93 & 14.95 & 32.59 \\
8 & 33.96 & 31.91 & 31.91 & 38.77 \\
9 & 38.31 & 37.25 & 40.74 & 27.74 \\
10 & 27.35 & 26.26 & 29.61 & 20.56 \\
\hline
\end{tabular}

Seperti yang terlihat pada Tabel 2, kuat tekan tertinggi dicapai pada komposisi 2 yaitu pada sampel pertama sebesar $51.52 \mathrm{~kg} / \mathrm{cm} 2$, sampel kedua sebesar $48.76 \mathrm{~kg} / \mathrm{cm} 2$ dan sampel ketiga sebesar $50.34 \mathrm{~kg} / \mathrm{cm} 2$ dengan nilai rata-rata sebesar $50.12 \mathrm{~kg} / \mathrm{cm} 2$. Sementara kuat tekan terendah diberikan oleh komposisi 5 dengan nilai kuat tekan rata-rata sebesar 11.84 $\mathrm{kg} / \mathrm{cm} 2$, dimana sampel pertama mempunyai kuat tekan sebesar $12.19 \mathrm{~kg} / \mathrm{cm} 2$, sampel kedua mencapai $12.82 \mathrm{~kg} / \mathrm{cm} 2$ dan sampel ketiga sebesar $10.54 \mathrm{~kg} / \mathrm{cm} 2$. Perbedaan kuat tekan ini tentu saja terjadi karena perbedaan proporsi bahan antar komposisi yang diamati. Selanjutnya akan dilakukan analisis menggunakan metode RSM untuk mencari komposisi yang paling optimum. Komposisi optimum yang diperoleh tidak lagi dalam bentuk proporsi seperti pada komposisi 1 sampai 10, melainkan dalam bentuk sebuah persamaan yang mengindikasikan proporsi dari masing-masing bahan, dimana $\mathrm{y}$ adalah respon dan $\mathrm{x}$ adalah variabel yang terkait dengan bahan.

\subsection{Analisis Hasil Eksperimen Dengan Metode Response Surface}

\subsubsection{Model orde I (linear)}

Pengujian regresi orde I ini dilakukan untuk mengetahui apakah variabel respon pada Tabel 1 berpengaruh signifikan secara linear atau tidak. Analisa dilakukan dengan bantuan software Minitab 17, yang hasilnya ditampilkan pada Tabel 3. 
Tabel 3. Output hasil analisis model Orde I dengan software Minitab 17

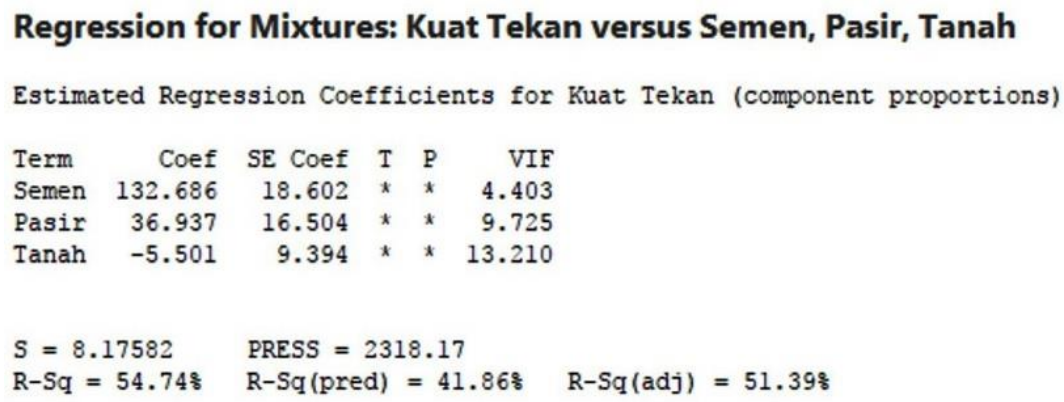

Hasil analisis Orde I yang diperlihatkan pada Tabel 3 menunjukan bahwa nilai $F_{\text {hitung }}$ adalah 16.33 dan $\mathrm{P}$ valuenya adalah $<0,0001$. Untuk mengambil keputusan, maka perlu dicari terlebih dahulu nilai $\mathrm{F}_{\text {Tabel. }}$. Nilai ini diperoleh dengan terlebih dahulu mencari $\mathrm{v}_{\mathbf{1}}$, yakni derajat kebebasan atau degree of freedom ( $d f$ ) yang bisa diperoleh dari output Minitabnya. Kemudian dicari nilai $\mathrm{v}_{2}$ yang diperoleh dengan mengurangi jumlah total sampel $(\mathrm{N})$ dengan jumlah variabel bebas atau jumlah faktornya (a), $\mathrm{v}_{2}=\mathrm{N}-\mathrm{a}$, sehingga diperoleh $\mathrm{v}_{1}=2, \mathrm{v}_{2}=27$. Dari tabel statistik untuk mendapatkan nilai $\mathrm{F}$ pada tingkat signifikansi $(\alpha) 5 \%$ diperoleh nilai $\mathrm{F}_{\text {Tabel }}=3,35$. Terlihat disini bahwa nilai $\mathrm{F}_{\text {Hitung }}>\mathrm{F}_{\text {Tabel }}$, artinya variabel berpengaruh signifikan terhadap respon. Tabel 3 juga memperlihatkan nilai $\mathrm{P}$ yang sangat kecil, kurang dari 0,0001; jauh lebih kecil dari tingkat signifikansi yang sudah ditentukan yakni 0,05. Karena nilai $\mathrm{P}$ nya lebih kecil dari $\alpha$, maka hal tersebut berarti variabel berpengaruh signifikan terhadap respon. Karena semua variabel berpengaruh signifikan terhadap respon, maka dapat dikatakan bahwa ada kesesuaian antara model yang dihasilkan dengan model Orde I. Namun demikian, untuk memastikan bahwa model ini benar-benar sesuai dengan model Orde I, maka harus dilakukan pengujian lack of fit. Hipotesis yang digunakan pada pengujian lack of fit adalah:

$\mathrm{H}_{0}=$ Tidak ada lack of-fit dalam model orde I

$\mathrm{H}_{1}=$ Ada lack of-fit dalam model orde I. 
Seperti yang dapat dilihat pada Tabel 3, untuk uji lack of fit, nilai $\mathrm{F}_{\text {hitung }}$ nya adalah 113,62 dan $P$ valuenya adalah $<0,0001$. Karena nilai $F_{H i t u n g}$ nya ternyata lebih besar dari nilai $F_{\text {Tabel }}$, maka hipotesis nolnya ditolak. Sebagai konsekuensinya, hipotesis alternatif $\left(\mathrm{H}_{1}\right)$ diterima, yang bermakna bahwa ada lack of fit dalam model Orde I. Artinya, terdapat ketidakcocokan antara model yang dibangun dengan model Orde $\mathrm{I}$. Nilai $\mathrm{F}_{\text {Tabel }}$ untuk uji lack of fit berdasarkan nilai $\mathrm{v}_{1}=7, \mathrm{v}_{2}=27$ adalah 2,37. Karena uji lack of fit tidak lolos, maka dapat dikatakan bahwa model yang digunakan pada percobaan Orde I belum sesuai, sehingga percobaan akan dilanjutkan dengan pendugaan pada model yang lebih tinggi yaitu model Orde II.

\subsubsection{Model orde II (quadratic)}

Desain eksperimen quadratic pada tahap kedua digunakan untuk mengetahui apakah variabel input pada tabel diatas berpengaruh signifikan secara quadrat atau tidak. Hasil analisa dengan software Minitab 17 ditampilkan pada Tabel 4. Seperti yang dapat dilihat pada tabel tersebut, semua nilai $\mathrm{F}_{\text {hitung }}$ lebih besar dari nilai $\mathrm{F}_{\text {Tabel }}(2,57 ; 3,35 ; 2,96$ dan 4,21) masing-masing untuk jumlah sampel $\mathrm{v}_{2}=27$ dan nilai $\mathrm{v}_{1}=5,3,2$ dan 1) yang diperoleh dengan cara yang sama pada model Orde I. Demikian pula dengan P valuenya adalah 0,00. Sehingga dapat disimpulkan bahwa secara bersama-sama semua variabel bebas baik secara linear, kuadrat dan interaksi berpengaruh signifikan terhadap respon. Tahap selanjutnya adalah melakukan pengujian lack of fit. Sama seperti prosedur pada model Orde I, terlebih dahulu harus dinyatakan hipotesisnya, yakni:

$\mathrm{H}_{0}=$ Tidak ada lack of-fit dalam model orde II

$\mathrm{H}_{1}$ = Ada lack of-fit dalam model orde II

Seperti yang dapat dilihat pada Tabel 4, untuk uji lack of fit, nilai $F_{\text {hitung }}$ nya adalah 1,44 dan $P$ value sebesar 0,257. Karena nilai $F_{\text {Hitung }}$ nya lebih kecil dari nilai $F_{\text {Tabel }}=2,74$ (untuk $\mathrm{v}_{2}=$ 27 dan $\mathrm{v}_{1}=4$ ), maka hipotesis nolnya (yang menyatakan tidak ada lack of fit) diterima. Artinya, model yang dibangun mempunyai kecocokan dengan model Orde II. Nilai P untuk uji lack of fit ini, yakni 0,257, juga lebih besar dari 0,05 yang bermakna bahwa tidak ada lack of fit dari model yang didapatkan. Dengan demikian dapat diambil kesimpulan bahwa model pada percobaan Orde II dikatakan sesuai. Hasil analisis model Orde II yang ditunjukan pada Tabel 4 juga memperlihatkan koefisien masing-masing variabel bebas dan juga interaksi antar variabelnyanya, sehingga diperoleh sebuah persamaan Orde II nya, yaitu: $y=$ $-5,56 x_{1}+0,141 x_{2}+0,541 x_{3}+0,214 x_{1} x_{2}+0,0473 x_{1} x_{3}-0,0307 x_{2} x_{3}$. Atau dalam bentuk lain $\mathrm{y}=-5,46$ semen $+0,141$ pasir $+0,541$ tanah liat $+0,214$ interaksi semen dengan pasir + 0,0473 interaksi semen dengan tanah liat - 0,0307 interaksi pasir dengan tanah liat.

\subsection{Pengujian Model Eksperimen}

\subsubsection{Uji koefisien regresi secara serentak}

Untuk memeriksa signifikansi model orde II dapat dilakukan dengan melihat regression analisa model orde II dimana $\mathrm{P}$ value untuk regresi linier maupun kuadratik lebih kecil dari nilai $\alpha$. Hal ini berarti bahwa variabel bebas memberikan kontribusi signifikan terhadap respon atau model yang terbentuk. Pengujian model secara serentak ini juga dapat dilakukan dengan menggunakan uji F. Nilai F untuk model linier dan quadratik masingmasing adalah sebesar 142,24 dan 245.16, sementara dari tabel diperoleh nilai F sebesar 2.96 untuk model linier dan 3,35 untuk model quadratik. Karena $\mathrm{F}_{\text {Hitung }}>\mathrm{F}_{\text {Tabel, }}$, maka dapat disimpulkan bahwa variabel bebas secara bersama-sama memberikan pengaruh yang 
signifikan terhadap respon. Atau dengan kata lain, ketiga faktor (semen, pasir dan tanah liat) mempunyai pengaruh yang signifikan terhadap kuat tekan dari bata non bakar.

Tabel 4. Output hasil analisis model Orde II dengan software Minitab 17

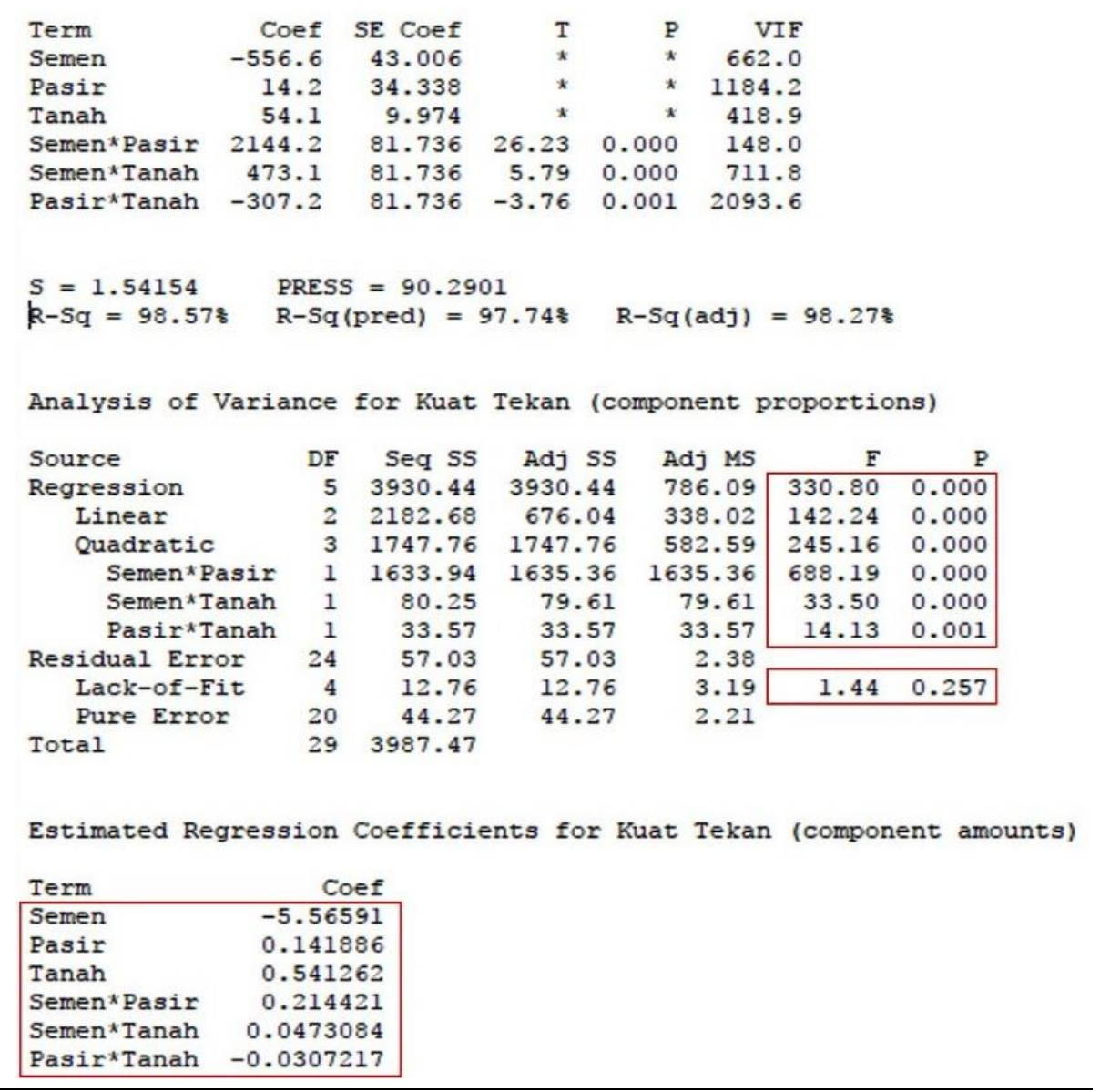

\subsubsection{Uji identik}

Pengujian asumsi identik bertujuan untuk memeriksa apakah variansi residual dari model yang diperoleh sama penyebarannya. Untuk itu diplot hubungan antara residual dengan fitted value yang hasilnya ditampilkan pada Gambar 1. Terlihat pada gambar ini bahwa residual tersebar secara acak dan tidak membentuk pola tertentu yang bermakna bahwa asumsi residual identik terpenuhi. Residualadalah selisih antara respon dari model optimasi dangan model sebenarnya, sedangkan fitted value adalah model baru variable responnya. Jika plot residual tiap sampel mempunyai kesamaan penyebaran akan menyebabkan ketidakvalidan dari model optimasi yang diperoleh. 


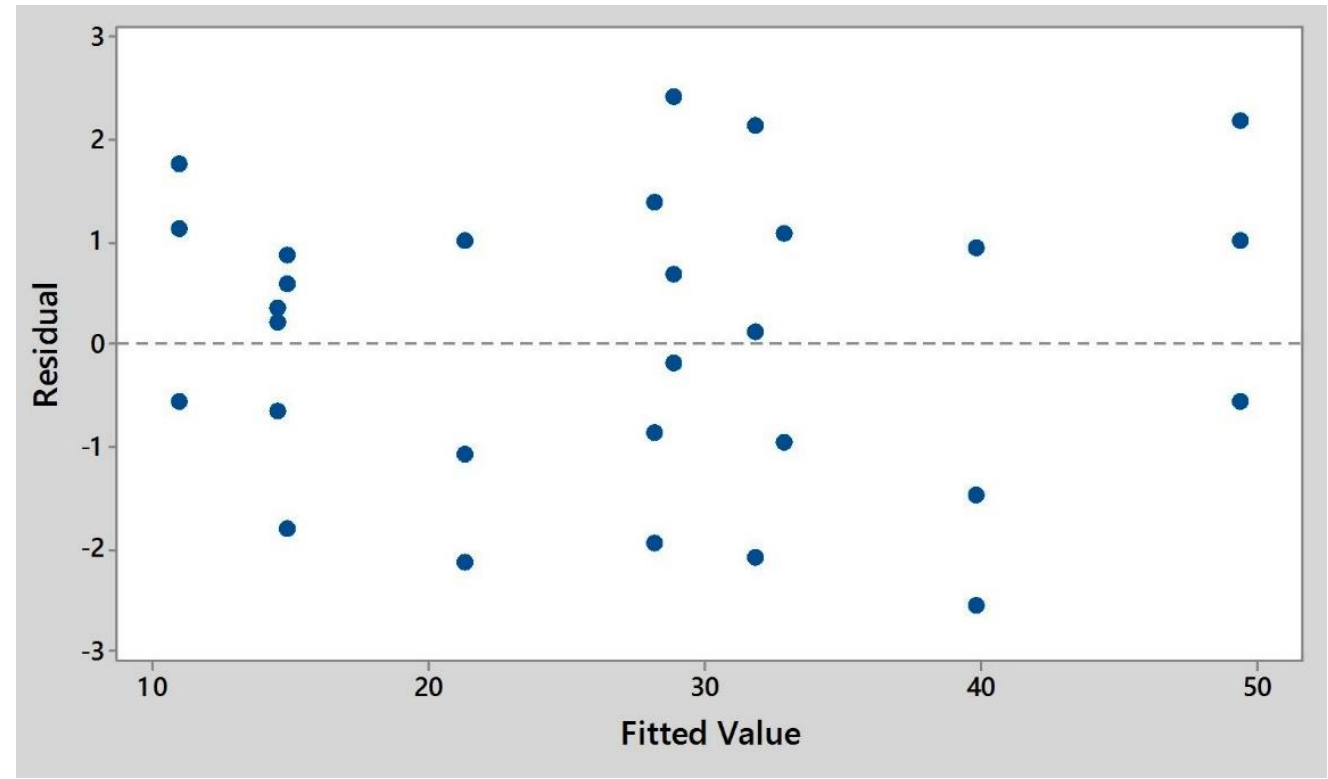

Gambar 1. Uji identik residual versus fitted value

\subsubsection{Uji distribusi normal}

Uji distribusi normal dilakukan untuk mengamati penyimpangan model. Residual dikatakan telah mengikuti distribusi normal jika pada plot kenormalan residual, titik residual yang dihasilkan telah sesuai atau mendekati garis lurus yang ditentukan. Hasil plotting distribusi normal diperlihatkan pada Gambar 2, dimana salah satu informasi penting yang bisa diperoleh adalah nilai statistik Kolmogorov-Smirnov (KS) untuk uji distribusi normal. Terlihat pada gambar tersebut bahwa nilai nilai statistik KolmogorovSmirnov adalah 0,136 kurang dari nilai statistik Kolmogorov sebesar 0,210 sehingga dapat dikatakan bahwa uji kenormalan residual telah mengikuti distribusi normal. Terlihat dengan jelas pada Gambar 2 bahwa plot residual mendekati garis lurus sehingga bisa dikatakan eror tidak melenceng dari substansi distribusi normal. Suatu respon tidak berdistribusi normal apabila bentuk fungsi regresinya tidak tepat atau tidak sesuai.

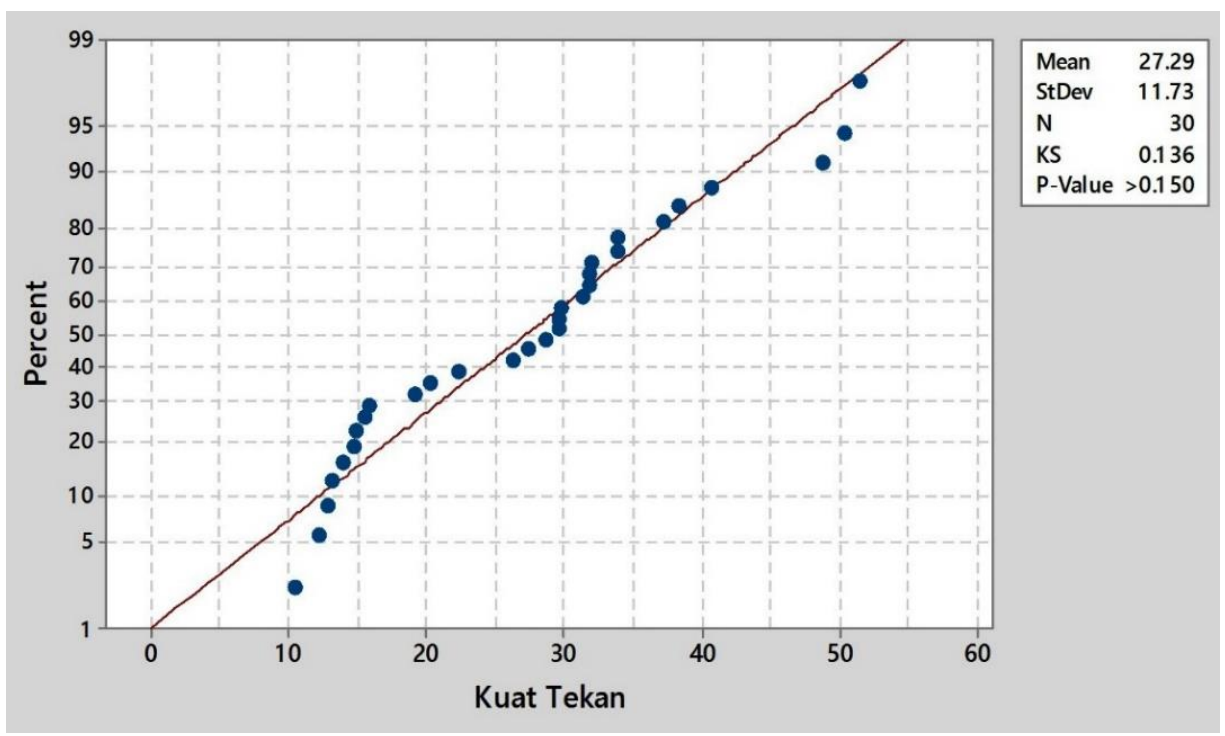

Gambar 2. Hasil uji distribusi normal 


\subsection{Analisis Karakteristik Permukaan Respon}

\subsubsection{Plot kontur dan permukaan (contour and surface plot)}

Seperti yang sudah dikatakan sebelumnya, metode response surface adalah suatu metode yang menggabungkan teknik matematika dengan teknik statistika dalam membuat model dan menganalisis suatu respon yang dipengaruhi oleh beberapa variabel bebas atau faktor dengan tujuan mengoptimalkan respon tersebut (Montgomery, 2009). Salah satu cara untuk menunjukkan model response surface adalah membuat plot kontur respon yang berupa kuat tekan dengan tiga faktor yang mempengaruhi respon yaitu komposisi semen, pasir dan tanah. Hasil analisis dengan software Mintab 17 menghasilkan dua gambar berupa grafik contour dan surface seperti yang ditunjukkan pada Gambar 3.
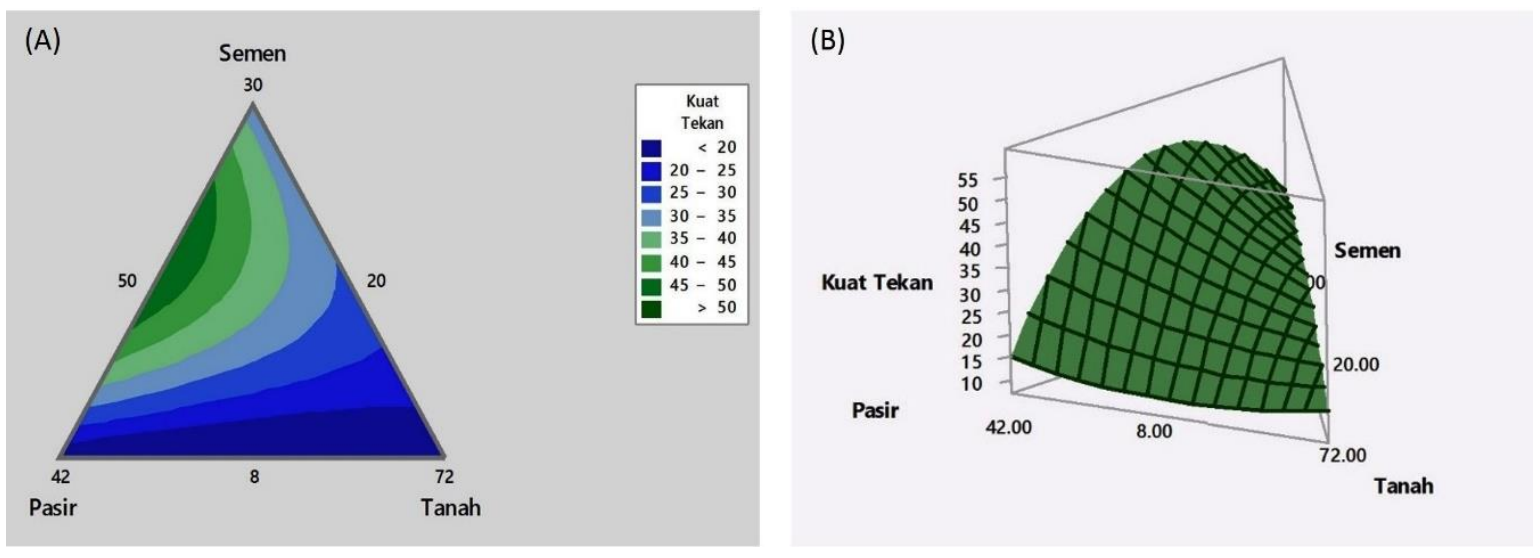

Gambar 3. Karateristik permukaan respon berupa; (A) contour plot, dan (B) surface plot

Gambar 3 (A) menunjukkan contour plotyang dihasilkan, terdiri dari berbagai variasi warna yang masing-masing menunjukkan range besarnya respon yang dihasilkan. Kondisi paling maksimal untuk plot diatas berada di warna hijau tua dengan nilai kuat tekan diatas 50 $\mathrm{kg} / \mathrm{cm}^{2}$. Range warna inilah yang akan memberi garis besar petunjuk letak titik optimum variabel. Penentuan kondisi optimum dari faktor diatas dibuktikan dengan bentuk kurva tiga dimensi yang membentuk puncak optimum seperti ditunjukkan pada Gambar 3 (B). Gambar ini menampilkan contour plot dalam tiga dimensi. Terlihat dengan jelas bahwa kuat tekan akan semakin besar apabila proporsi semen berada pada proporsi $21 \%$, proporsi pasir sebesar $29 \%$, dan proporsi tanah sekitar $50 \%$. Nilai tersebut hanya berupa perkiraan kasar saja, masih sulit untuk mengetahui dengan jelas besarnya variabel independen $\left(\mathrm{x}_{1}, \mathrm{x}_{2}\right.$ dan $\left.\mathrm{x}_{3}\right)$ yang mampu mengoptimalkan respon dengan plot permukaan respon, sehingga perlu dilakukan optimasi lanjutan lagi dengan menggunakan fitur optimazion plot pada Minitab 17 .

\subsubsection{Plot optimasi (optimazion plot)}

Untuk menentukan kombinasi level-level variabel proses yang dapat menghasilkan respon yang optimal dapat dilakukan dengan bantuan optimazion plot yang ada pada software Minitab dengan cara random di pusat kontur optimum. Penentuan kombinasi level-level ini berdasarkan analisis data tahap dua dengan model quadratik sehingga bissa diperoleh proporsi setiap variable $\mathrm{x}_{1}, \mathrm{x}_{2}$, dan $\mathrm{x}_{3}$ yang akan menghasilkan respon y yang paling optimal. Hasil optimization plot diperlihatkan pada Gambar 4, yang menunjukan dengan jelas proporsi untuk setiap variable bebas yang akan menghasilkan variabel respon yang paling besar. Dimana untuk variable semen $\left(\mathrm{x}_{1}\right)$ sebesar $21.034 \%$ dan variabel pasir $\left(\mathrm{x}_{2}\right)$ sebesar 
$28.9651 \%$. Sedangkan variabel tanah tidak terlalu berpengaruh secara signifikan pada model eksperimen. Ini dapat terlihat dari optimum plot yang membentuk kurva linar yang berarti dengan penambahan variabel ini akan menurunkan respon yang didapatkan. Namun pada pembuatan bata non bakar tanah liat merupakan bahan utama, jadi tanah liat harus tetap memiliki kontribusi pada komposisi campuran. Sehingga untuk mendapatkan nilai kuat tekan $50 \mathrm{~kg} / \mathrm{cm}^{2}$ maka digunakan komposisi tanah sekitar $50 \%$ dari komposisi total.

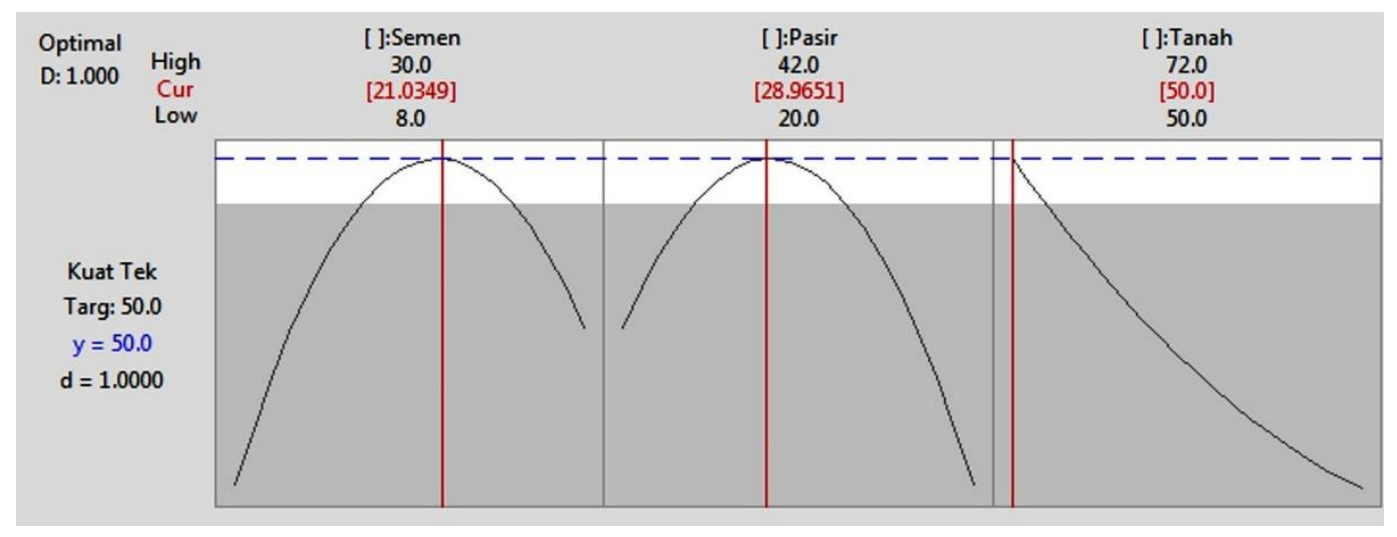

Gambar 4. Hasil optimum plot (optimization plot)

\section{KESIMPULAN}

Sebuah studi yang berhubungan dengan aplikasi metode respon permukaan (Response Surface Method), sebuah metode desain eksperimen berbasis analisa statistik, telah menghasilkan sebuah komposisi optimum bahan penyusun bata non bakar yang menghasilkan kuat tekan paling optimum. Secara umum kesimpulan yang bisa diambil dari penelitian ini adalah proporsi bahan yang dapat menghasilkan kuat tekan yang paling optimal untuk bata non bakar adalah 21,034\% semen, 28,9651\% pasir dan 50\% tanah. Proporsi campuran ini mampu menghasilkan bata non bakar dengan kuat tekan rata-rata sebesar $50.22 \mathrm{~kg} / \mathrm{cm}^{2}$. Hasil studi ini juga merekomendasikan sebuah persamaan umum untuk memprediksi kuat tekan bata non bakar apabila menggunakan ketiga bahan tersebut, yaitu: $y=-5,56 x_{1}+0,141 x_{2}+0,541 x_{3}+0,214 x_{1} x_{2}+0,0473 x_{1} x_{3}-0,0307 x_{2} x_{3}$.

\section{REFERENSI}

Amin, M., 2014, Inovasi Material pada Pembuatan Bata Merah Tanpa Bakar untuk Kemakmuran Industri Kerakyatan, UPT Balai Pengolahan Mineral, Lampung.

ASTM., 2002, ASTM C67-02: Standard Test Methods for Sampling and Testing Brick and Structural Clay Tile, US.

Dewi, A.K., Sumarjaya, I.W., Srinadi, I.G.A.M., 2013, Penerapan Metode Permukaan Respons Dalam Masalah Optimalisasi, E-Jurnal Matematika, Vol 2 (2): 32-36.

Ernawati., 2012, Identifikasi Pengaruh Variabel Proses dan Penentuan Kondisi Optimum Dekomposisi Katalik Metana dengan Metode Respon Permukaan, Universitas Indonesia, Jakarta.

Fajrin, J., Zhuge, Y., Bullen, F., Wang, H., 2011-a, Flexural Strength of Sandwich Panel with Lignocellulosic Composites Intermediate Layer-a Statistic Approach, International Journal of Protective Structures, Vol 2 (4): 453-464.

Fajrin, J., Zhuge, Y., Bullen, F., Wang, H., 2011-b, The Implementation of Statistical Inference to Study the Bending Strength of Sustainable Hybrid Sandwich Panel, Advanced Material Research, Vol 250-253: 956-961.

Fajrin, J., Zhuge, Y., Bullen, F., Wang, H., 2013, Significance Analysis of Flexural Behaviour of Hybrid Sandwich Panels, Open Journal of Civil Engineering, Vol 3: 1-7. 
Fajrin, J., Zhuge, Y., Bullen, F., Wang, H., 2015, Improving the Quality of Experimental Research in Civil Engineering by Employing Statistical Design of Experiment; A case Study in Developing Composite Hybrid Sandwich Panel, Proceeding of the 14th International Conference QIR (Quality in Research), Mataram, 2015.

Fajrin, J., 2016, The Application of Statistical Design of Experiments to Study the In-plane Shear Behaviour of Hybrid Composite Panel, Journal of Civil Engineering Dimension, Vol 18 (1): 2530.

Fajrin, J., Pathurahman, P., Pratama, L.G., 2016, Aplikasi Metode Analysis of Variance (ANOVA) Untuk Mengkaji Pengaruh Penambahan Silica Fume Terhadap Sifat Fisik dan Mekanik Mortar, Jurnal Rekayasa Sipil, Vol 12 (1): 11-23.

Maryati, E., 2015, Kajian Penerapan Metode Permukaan Respon Pada Formula Jamu Antidiabetes Dengan Ikan Zebra (Danio Rerio) Sebagai Hewan Uji,Institut Pertanian Bogor, Bogor.

Montgomery, D.C., 2009, Design and Analysis of Experiments , John Wiley \& Sons Inc, New York.

Primayatma, I.B.G., 1993, Peranan Semen Portland dan Agregat Liat Terhadap Campuran Tanah Liat Sebagai Bahan Batu Bata Merah Tanpa Pembakaran, dalam (Sudarsana, I.K., Budiwati, I.A.M., Wijaya, Y.A., 2011, Karakteristik Batu-Bata Tanpa Pembakaran Terbuat Dari Abu Sekam Padi dan Serbuk Batu Tabas, Jurnal Ilmiah Teknik Sipil, Vol 15(1): 93-101.

Sudarsana, I.K., Budiwati, I.A.M., Wijaya, Y.A., 2011, Karakteristik Batu-Bata Tanpa Pembakaran Terbuat Dari Abu Sekam Padi dan Serbuk Batu Tabas, Jurnal Ilmiah Teknik Sipil, Vol 15(1): 93101. 